\title{
行列安定超立方体の簡単な推定法
}

\author{
森 武宏 $^{* *}$ ・小亀 英己 $^{* * *}$
}

\section{A Simple Estimate for Matrix Stability Hypercube*}

Takehiro MorI $^{* *}$ and Hideki KoKAME ${ }^{* * *}$

\section{1.はじめに}

ロバスト制御の研究のよく知られたトピックスの一つ として, 行列の安定半径を計算する問題がある. これは, 次のようなものである. $A=\left\{a_{i j}\right\} \in R^{n \times n}$ を $\mathscr{M}$ (フル ヴィッツ行列のクラス) に属する名目行列, $E=\left\{e_{i j}\right\}$ を任意の $n$ 次正方摂動行列として, $A+E \oplus \mathscr{H}$ となる

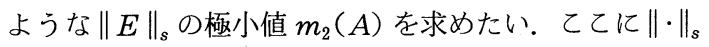
は, ユークリッド行列ノルムである. したがって, 安定 半径は行列要素空間に括いて $l^{2}$ ノルムで安定余裕を測 ることに対応している．乙の值は， $E \in C^{n \times n}$ のときに は陽に求められ, $m_{2}(A)=\inf _{\omega} \sigma_{\min }(j \omega I-A)$ と表わ される.ただし， $\sigma_{\min }(\cdot)$ は行列の最小特異值を指し， $I$ は単位行列である. しかし実際に, 工学で要求される $E \in R^{n \times n}$ の場合には, $m_{2}(A)$ は一般に閉じた形では おろか, 数值的に求めることもおぼつかなかったため, その代償に下界值が数多く報告されてきた(たとえば, 参考文献 2) を参照されたい). しかし，最近に至りよう やく計算法が見いだされたてとが報じられている゙．上 ころで, この安定半径の定義では, 十分満たされない点 がある. それは, $m_{2}(A)$ は直接 $A$ の各要素 $a_{i j}$ の許容 変動範囲を与えるあのではないてとである.

本報告では, この点に鑑み, 行列要素空間で $l^{\infty}$ ノル ムを用いて安定余裕を推定することを考える.すなわち, $\|E\|_{H}:=\max _{i, j}\left|e_{i j}\right|$ を採用し, 要素空間で $A$ を中心 とした安定超立方体の大きさを簡単に推定する方法を提 案する.

* 1993 年 11 月 2 日受付

** 京都工芸繊維大学 工芸学部 Department of Electronics and Information Science, Kyoto Institute of Technology ; Goshokaido-cho, Matsugasaki, Sakyo ward, Kyoto city, Kyoto 606, JAPAN.

*** 大阪工業大学 電気工学科 Department of Electorical Engineering, Osaka Institute of Technology ; Ohmiya, Asahi ward, Osaka city, Osaka 535, JAPAN.

Key Words : stability robustness, matrix stability hypercube, coefficient perturbation, estimate, matrix inversion.

\section{2. 主要な結果と検討}

まず，乙てで扱う問題を改めて記述しておてう．安定 な名目行列 $A=\left\{a_{i j}\right\} \in R^{n \times n}$ と摂動行列 $E=\left\{e_{i j}\right\} \in$ $R^{n \times n}$ を考えたとき, 行列要素空間での安定超立方体の 大きさ (一辺の長さの $1 / 2)$ を与える,

$$
\begin{gathered}
\mu_{H}(A):=\inf \left\{\|E\|_{H}: \exists i, \operatorname{Re} \lambda_{i}(A+E) \geq 0,\right. \\
\left.E \in R^{n \times n}\right\}
\end{gathered}
$$

を推定したい. ここに, $\lambda_{i}(\cdot)$ は行列の固有値を示す. 上式右辺, 仮定 $A \in \mathcal{S}$ 抢よび行列固有值の要素に関 する連続性から，乙の限界を与える $E$ は $A+E$ の固有 值の少なくとも一つを虚軸の上に至らしめるあのである. この条件を表現するため, $A$ 亿対しクロネッカ和, $K_{A}:=$ $A \oplus A=A \otimes I+I \otimes A$ を構成する.乙こに, $\otimes$ はク ロネッカ積を示す記号である. てのとき, $K_{A}$ の $n^{2}$ 個 の固有值, $\lambda_{k}\left(K_{A}\right), k=1, \cdots, n^{2}$ は,

$$
\lambda_{k}\left(K_{A}\right)=\lambda_{i}(A)+\lambda_{j}(A), i, j=1, \cdots, n
$$

のように表わせるてとが知られている ${ }^{4)}$. これより, 一 般にその固有值がすべて複素閉左半平面にある行列 $A$ が，虚軸上に少なくとあ一つの固有値をあつための必要 十分条件は, $\operatorname{det} K_{A}=0$ となることであることがわか る.ここでは $A$ の安定性を仮定したから $K_{A}$ は正則で あり, $K_{A}^{-1}:=\left\{\gamma_{i j}\right\}$ が存在することに注意しよう.

以上の準備のもとに, 本稿の主要な結果は次のようで ある.

【定理】スカラ量 $m_{H}(A)$ を,

$$
m_{H}(A):=\frac{1}{2} \cdot\left(\sum_{i, j=1}^{n^{2}}\left|\gamma_{i j}\right|\right)^{-1}
$$

としたとき， $m_{H}(A) \leq \mu_{H}(A)$ となる.つまり，

$$
\|E\|_{H}=\max _{i, j}\left|e_{i j}\right|<m_{H}(A)
$$

が成り立つ限り， $A+E \in \mathscr{C}$ 亡なっている.

この定理の証明の鍵となるのは, 次の古典的な結果であ る. 
【補題】占) 則な正方行列 $X$ に対して $X^{-1}=\left\{z_{i j}\right\}$ とし, $\eta:=\left(\sum\left|z_{i j}\right|\right)^{-1}$ とする. 任意の $X$ と同じサイズ の正方行列 $Y=\left\{y_{i j}\right\}$ が $\left|y_{i j}\right|<\eta, \forall i, j$ を満足する とき, $\operatorname{det}(X+Y) \neq 0$ である.

（定理の証明）先に述べたてとから，(4) 式が成り 立つならば, $\operatorname{det} K_{A+E} \neq 0$ となることを示せばよい。 ここで二つの事実を利用する。 一つは， $K_{A}$ の $A$ 亿関 する線形性，つまり， $K_{A+E}=K_{A}+K_{E}$ となることで あり, 残る一つは $\left\|K_{E}\right\|_{H} \leq 2\|E\|_{H}$ である. 後者の 関係式はクロネッカ和 $K_{E}$ およびノルム $\|\cdot\|_{H}$ の定義よ り明らかである。補題に扔いて， $X, Y$ をそれぞれ $K_{A}, K_{E}$ と抢けば，求める関係は直ちに得られる.

(証明終)

以下に，ての結果についての注記事項を述べておく。

（1）定理では，通常要求される最適值を求めるいか なる計算む不要で，実質的には逆行列の計算が すべてである.しかし，逆を求めなければなら

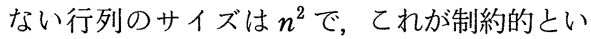
えば制約的である。けれどあ，乙れは行列を対 象之する限り，払わなければならないコストで あろうと考えられる。

（2）乙こで用いたノルム，すなわち安定超立方体の 利点は，(4) 式のように名目行列 $A$ の要素 $a_{i j}$ の許容摂動範囲を直接表現している点である. しかしてのノルムは, 通常の行列ノルムに要求 される性質をすべて満たしている訳ではないて とに注意しょう。たとえば，二つの行列の積に 関するノルム不等式は成り立たない。つまり， $X, Y$ を再び任意の正方行列としたとき, $\|X Y\|_{H} \leq\|X\|_{H}\|Y\|_{H}$ は一般に成り立ってい ない.

（3）よく知られているように， $K_{A}$ は，Lyapunov 行列方程式, $A P+P A^{\prime}=Q, P, Q \in R^{n \times n}$ を 標準的な一次方程式に書き直した $K_{A} p=q$ の 係数行列である. こてに，p, $q$ は，それぞれ行 列 $P, Q$ の行展開，すなわちそれらの行を順に スタックしていって求められる $n^{2}$ ベクトルで ある。 乙の方程式が，一意解をあつための限界 が, $\mu_{H}(A)$ となっている.

(4) 証明からわかるように，乙てでは $K_{A}$ の $A$ に 関する線形性が一つのポイントとなっている. したがって，並行した議論によってシュール安
定超立方体の大きさを推定することは叶わない． そのためには, クロネッカ“積”， $A \otimes A$ を用 いなければならず，線形性は成り立たないから である.

（5）とくに $\left\|K_{E}\right\|_{H}=2\|E\|_{H}$ の成り立つとき，た とえば $\|E\|_{H}$ が $E$ の対角要素によって達成さ れるようなときには，結果の鋭さ，つまり $\mu_{H}(A)$ 之 $m_{H}(A)$ の隔たりは, 補題の条件の 鋭さのみに依っていることがわかる.

（6）行列の安定余裕を求める他の一つの方法は, 参 考文献1)に引用されているGastinel-Kahan 定理を使うことである.しかし，そのためには ノルムとしてベクトルノルムから誘導された行 列ノルムを用いるという前提を満たさなければ

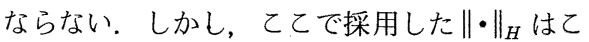
の前提を満たさないと考えられる。

\section{3. おわりに}

フルヴィッツ安定な名目行列に対して, 係数空間でて れを中心にした安定超立方体の大きさを簡単に推定する 方法を提案した. 一般に, どのようなノルムを用いるに しろ, 正確な安定余裕の計算には非線形最適化計算を含 む相当の労力を要する. てのことも，その下界が数多く 報告されてきた理由である. 本稿の寄与は, 新たなノル ムを採用したてとと共に，既存の下界にさらに計算容易 なオプションを付け加えた点にある. 最後に, 参考文献 5） の内容を御教示くださった, 本学中岡明教授に御礼申し 上げる。

\section{参 考 文 献}

1) J. M. Martin : State-Space Measures for Stability Robustness ; IEEE Trans. on Automat. Contr., Vol. 32, No. 6, pp. 509 512 (1987)

2) L. Qiu and E. J. Davison: The Stability Robustness Determination of State Space Models with Real Unstructured Perturbations; Math. Control, Signals and Systems, Vol. 4, pp. 247 267 (1991)

3) L. Qiu, B. Bernhardsson, A. Rantzer, E. J. Davison, P. M. Young and J. C. Doyle: On the Real Structured Stability Radius ; Proc. of 12th IFAC World Congress, Vol. 8, pp. 71 78 (1993)

4) P. Lancaster and M. Tismenetsky : The Theory of Matrices, Academic (1985)

5) M. A. Ostrowskii : Sur le Détermination des Bornes Inférieurs pour une Classe des Determinants ; Bull. Sc. Math., Vol. 61, pp. 19 32 (1937) 